\title{
PENYELENGGARAAN PROGRAM SD-SMP SATU ATAP PADA DAERAH TERPENCIL DALAM LATAR BUDAYA RUMAH BETANG KALIMANTAN TENGAH
}

\author{
Rudi Hasan \\ Dinas Pendidikan Provinsi Kalimantan Tengah \\ E-mail: rudihasankalteng@gmail.com
}

\begin{abstract}
Abstrak: Tujuan penelitian ini adalah mendeskripsikan penyelenggaraan program SD-SMP Satu Atap sebagai alternatif pemerataan pendidikan dasar sembilan tahun pada daerah terpencil dalam latar budaya rumah betang Kalimantan Tengah. Penelitian ini merupakan penelitian kualitatif dengan rancangan studi multi situs pada 3 SMPN Satu Atap di wilayah Kabupaten Gunung Mas. Pengumpulan data dilakukan dengan metode: wawancara mendalam (indepth interview), observasi partisipan (participant observation), dan studi dokumentasi (study of document). Penetapan sumber data dilakukan dengan teknik purposive sampling. Analisis data dilakukan melalui kegiatan mengorganisasi data, menata dan membagi data dalam unit-unit yang dapat dikelola, mensitesis, mencari pola, menemukan apa yang bermakna dan apa yang diteliti untuk diputuskan dan dilaporkan dengan sistematis (Bogdan dan Biklen, 1998). Analisis data dalam penelitian ini dilakukan dalam dua tahap, yaitu: analisis data tiap situs (situs tunggal) dan analisis data lintas situs. Pengecekan keabsahan data dilakukan dengan menggunakan derajat kepercayaan (credibility) melalui teknik triangulasi baik sumber maupun metode. Hasil penelitian menemukan bahwa nilai-nilai budaya rumah betang yang mendasari dalam penyelenggaraan SD-SMP Satu Atap muncul pada: (1) struktur birokrasi, meliputi: SOP, koordinasi dan pemberdayaan SDM; (2) sumberdaya, meliputi: SDM, sarana prasarana dan pembiayaan; dan (3) komunikasi, meliputi: komunikasi intern, dengan SD penyangga, dengan dinas terkait, dan masyarakat sekitar sekolah.
\end{abstract}

Kata Kunci: SD-SMP Satu Atap, Daerah Terpencil, Budaya Rumah Betang.

\begin{abstract}
The purpose of this study is to describe the implementation of the One-Roof Junior Secondary School as an alternative to the distribution of nine-year basic education in remote areas in the cultural setting of Central Kalimantan Betang Houses. This research is a qualitative research with a multi-site study design on 3 One-Roof Junior Secondary Schools in Gunung Mas Regency. Data collection is done by methods: in-depth interviews (indepth interview), participant observation (participant observation), and study documentation (study of document). Determination of data sources is done by using purposive sampling technique. Data analysis is done through the activities of organizing data, organizing and dividing data into units that can be managed, mensiteis, looking for patterns, find what is meaningful and what is researched to be decided and reported systematically (Bogdan and Biklen, 1998). Data analysis in this research was carried out in two stages, namely: data analysis for each site (single site) and cross-site data analysis. Checking the validity of the data is done by using a degree of credibility through both source and method triangulation techniques. The results of the study found that the values of the betang house culture that underlies the implementation of the One-Roof Junior Secondary School appeared on: (1) bureaucratic structure, including: SOP, coordination and empowerment of HR; (2) resources, including: human resources, infrastructure and financing; and (3) communication, including: internal communication, with supporting elementary schools, with related agencies, and the community around the school.
\end{abstract}

Keywords: One-Roof Junior Secondary School, Remote Area, Betang House Culture.

\section{PENDAHULUAN}

Secara tegas, Undang-Undang

Dasar 1945 Pasal 31 telah mengatur pendidikan bagi warga negara Indonesia, khususnya pada ayat (1) setiap warga negara berhak mendapat pendidikan dan ayat (2) setiap warga negara wajib mengikuti pendidikan dasar dan pemerintah wajib membiayainya. Selanjutnya berkaitan dengan pendidikan, 
secara rinci dijabarkan dalam UndangUndang Sistem Pendidikan Nasional (UUSPN) Nomor 20 Tahun 2003. Pada UUSPN No. 20 Tahun 2003 tersebut sebagai latar penelitian ini, lebih khusus mengatur pendidikan dasar sembilan tahun, yaitu pada pasal 6 dinyatakan, bahwa setiap warga negara yang berusia tujuh (7) sampai dengan lima belas (15) tahun wajib mengikuti pendidikan dasar. Salah satu alternatif pendidikan dasar sembilan tahun yang diselenggarakan untuk daerah terpencil dan jauh dari akses SMP pada umumnya adalah model pendidikan dasar terpadu antara SD dan SMP, yaitu penyelenggaraan program SDSMP Satu Atap.

Pada daerah terpencil dan terpencar, bahkan untuk daerah terisolir umumnya SMP belum didirikan sebagaimana mestinya atau SMP yang sudah ada berada di luar jangkauan lulusan SD setempat. Dikarenakan jumlah lulusan SD di daerah tersebut pada umumnya relatif sedikit, maka pembangunan Unit Sekolah Baru SMP dipandang tidak efisien berdasarkan sumber dana atau sumber daya lainnya. Tetapi di lain pihak, daerah tersebut biasanya merupakan daerah-daerah dimana APK untuk Sekolah Menengah Pertama (SMP) masih rendah dan merupakan lokasi tempat anak-anak yang belum memperoleh layanan pendidikan SMP atau yang sederajat. Pada hal, secara filosofi setiap manusia berhak mendapatkan skses peningkatan kualitas hidup, harkat dan martabat dimanapun berada tanpa memandang ras, suku atau etnik, agama, dan budaya apapun.

Salah satu aspek budaya berkaitan dengan penyelenggaraan program sekolah satu atap di Provinsi Kalimantan Tengah adalah budaya rumah betang. Adapun rumah betang adalah bentuk rumah panggung yang memanjang dengan tiang yang tinggi yang dihuni oleh beberapa keluarga yang terikat dengan nilai-nilai dan hukum adat Dayak. Rumah betang ini setara dengan nilai kerukunan yang diusung suku Dayak, khususnya di Kabupaten Gunung Mas sebagaian besar suku Dayak Ngaju (Kahayan). Rumah panjangpun kemudian dipandang sebagai sebuah komponen penting dalam menjaga kerukunan dan hubungan-hubungan yang lebih akrab. Rumah betang adalah rumah adat khas Kalimantan Tengah yang terdapat di berbagai penjuru Kalimantan Tengah, terutama di daerah hulu sungai yang biasanya menjadi pusat pemukiman suku Dayak (Kusni, 2009).

Nilai utama yang menonjol dalam kehidupan di rumah betang adalah nilai kebersamaan (komunalisme) di antara para warga yang menghuninya, terlepas dari perbedaan-perbedaan yang mereka miliki. Sehingga diketahui bahwa suku Dayak adalah suku yang menghargai suatu perbedaan, baik perbedaan etnik, agama ataupun latar belakang sosial lainnya. Budaya rumah betang adalah budaya yang menjunjung nilai kebersamaan, keakraban, kekeluargaan, persamaan hak, saling menghormati, loyalitas dan tenggang rasa.

Penyelenggaraan program sekolah satu atap sebagai salah satu bentuk penyelenggaraan kebijakan pemerataan pendidikan dasar sembilan tahun (PP RI No. 28 Tahun 1990), tidak lepas dari beberapa variabel pendukung program pada suatu lembaga atau sekolah. Berdasarkan beberapa hasil penelitian, variabel-variabel pendukung implementasi kebijakan suatu program, antara lain adalah regulasi, sikap pelaksana, stakeholders, kepemimpinan, komunikasi, sumber daya, struktur birokrasi, ekonomi, politik, sosial, strategi manajemen, legitimasi, monitoring dan evaluasi (Edward, 1980; Durn, 1981; Horn dan Meter, 1975 dalam Winarno, 2002; Brikenhorf dan Crosby, 2002).

Dalam penelitian ini dibahas secara mendalam variabel pendukung sebagai dimensi yang saling terkait pada penyelenggaraan program sekolah satu atap dengan dasar nilai-nilai budaya rumah betang. Adapun dimensi yang 
berhubungan dengan penyelenggaraan program sekolah satu atap dalam penelitian ini akan dijabarkan dalam subfokus pada tiga dimensi penyangga dalam penyelenggaraan program, yaitu struktur birokrasi, ketersediaan sumber daya pendidikan, dan komunikasi. Sehingga perlu dideskripsikan, bagaimana terkait ketiga hal tersebut dalam mendukung penyelenggaraan program sekolah satu atap pada daerah penelitian.

\section{METODE}

Penelitian ini menggunakan pendekatan kualitatif dengan rancangan studi multi situs pada 3 SMPN Satu Atap di wilayah Kabupaten Gunung Mas, yaitu: SMPN Satu Atap 1 Mihing Raya, SMPN Satu Atap 2 Kurun, dan SMPN Satu Atap 3 Tewah untuk melihat penyelenggaraan SD-SMP Satu Atap dalam latar budaya rumah betang Kalimantan Tengah pada aspek: (1) struktur birokrasi, (2) sumberdaya, dan (3) komunikasi. Pengumpulan data dilakukan dengan metode: wawancara mendalam (indepth interview), observasi partisipan (participant observation), dan studi dokumentasi (study of document). Penetapan sumber data dilakukan dengan teknik purposive sampling. Analisis data dilakukan melalui kegiatan mengorganisasi data, menata dan membagi data dalam unit-unit yang dapat dikelola, mensitesis, mencari pola, menemukan apa yang bermakna dan apa yang diteliti untuk diputuskan dan dilaporkan dengan sistematis (Bogdan dan Biklen, 1998). Analisis data dalam penelitian ini dilakukan dalam dua tahap, yaitu: analisis data tiap situs (situs tunggal) dan analisis data lintas situs. Pengecekan keabsahan data dilakukan dengan menggunakan derajat kepercayaan (credibility) melalui teknik triangulasi baik sumber maupun metode.

\section{HASIL DAN PEMBAHASAN \\ Hasil Penelitian \\ Struktur Birokrasi dalam \\ Penyelenggaraan program SD-SMP Satu Atap}

a) Standar Operasional Kerja

Aspek standar operasional prosedur atau acuan pelaksanaan secara umum sudah mengacu pada standar operasional kerja, hal ini terlihat pada: (1) kepala sekolah dalam penyelenggaraan program sekolah melibatkan seluruh komponen sekolah, (2) pembagian tugas dilakukan secara cermat dengan uraian tugas yang jelas, (3) kepala sekolah memberi kepercayaan penuh kepada guru dalam penyelenggaraan program sekolah, dan (4) pendekatan kekeluargaan yang akrab dilakukan untuk meningkatkan kesadaran guru dalam penyelenggaraan program sekolah, hal ini dilakukan dalam implementasi nilai-nilai yang tersirat dalam budaya rumah betang.

b) Koordinasi

Koordinasi dalam struktur birokrasi secara umum telah dilakukan dengan baik dan koordinatif, hal ini terungkap bahwa: (1) koordinasi dilakukan setiap waktu, karena ruangan guru dan kepala sekolah jadi satu, (2) koordinasi dengan pihak Dinas Pendidikan di Kabupeten dilakukan secara rutin dan intensif, (3) koordinasi dengan pengurus komite sekolah dilakukan secara proaktif, (4) pengelolaan SD dan SMP terpisah, tetapi koordinasi sering dilakukan secara kekeluargaan yang akrab dan kebersamaan seperti yang dianut dalam budaya rumah betang, dan (5) koordinasi sering dilakukan secara kekeluargaan yang akrab dan kebersamaan seperti yang dianut dalam budaya rumah betang.

c) Efisiensi Pemberdayaan Sumber Daya Manusia

Aspek efisiensi pemberdayaan sumber daya manusia terungkap dalam temuan penelitian, bahwa: (1) pemberdayaan sumber daya manusia didasarkan pada kemampuan dan kemauan (komitmen) dengan rasa tanggung jawab, (2) tidak membedakan guru yang berstatus PNS maupun guru honor dalam memberikan tugas-tugas sekolah, diutamakan mempunyai 
kemampuan dan kemauan (komitmen) tanpa mengabaikan yang lain, (3) pada penyelenggaraan program sekolah, kepala sekolah membagi tugas kepada guru sebagai wakasek, bendahara sekolah, wali kelas, pembina ekstrakurikuler, dan (4) solusi untuk mengatasi kekurangan guru mata pelajaran, beberapa guru ditugaskan mengajar dua mata pelajaran.

\section{Ketersediaan Sumber Daya Pendidikan dalam Penyelenggaraan Program SD- SMP Satu Atap}

\section{a) Sumber Daya Manusia}

Aspek sumber daya manusia terungkap pada temuan penelitian lintas situs, bahwa: (1) kepala sekolah masih baru dan pertama kali menjabat sebagai kepala SMP, sehingga masih "proses belajar" sebagai pimpinan di SMP, (2) secara kuantitas, jumlah guru masih kurang, Secara kuantitas, jumlah guru masih kurang terutama guru tetap (PNS), (3) secara kualitas, beberapa guru mengajar tidak sesuai latar belakang pendidikannya, (4) untuk meningkatkan profesionalitas guru dilibatkan mengikuti MGMP, (5) solusi kekurangan guru dilakukan dengan memberdayakan guru honorer (GTT), (6) belum adanya pegawai kependidikan untuk memperlancar penyelenggaraan program sekolah, seperti TU, laboran, pustakawan, cleaning service dan penjaga sekolah, (7) administrasi sekolah dikerjakan bersama oleh kepala sekolah, wakasek, dan guru di luar jam sekolah, dan (8) makna dalam keterbatasan memacu kepala sekolah dan guru untuk lebih kreatif dan inovatif dalam penyelenggaraan program sekolah.

b) Sumber Daya Fisik/ Prasarana dan Sarana

Aspek sumber daya fisik/ prasarana dan sarana terungkap dalam temuan penelitian lintas situs, bahwa: (1) bangunan utama untuk ruang kegiatan belajar siswa sudah ada dengan kondisi ruang sudah cukup representatif , (2) ruang guru dan ruang kepala sekolah masih jadi satu, dan belum representatif untuk ruang kerja baik guru maupun kepala sekolah, (3) toilet sebagai sanitasi sekolah sudah ada baik untuk siswa maupun guru meskipun masih minim, (4) fasilitas/prasarana belajar seperti, energi listrik, laboratorium dan perpustakaan masih belum ada, (5) buku sumber untuk penunjang proses belajar siswa masih kurang, (6) laptop/ komputer jumlahnya masih sangat terbatas, baik untuk kepentingan administrasi sekolah maupun menunjang pelajaran TI, dan (7) lapangan olah raga dan upacara jadi satu dengan SD penyangga.

c) Sumber Daya Pembiayaan atau Pendanaan

Aspek sumber daya pembiayaan atau pendanaan terungkap dalam temuan penelitian lintas situs ini bahwa: (1) semua sekolah telah melaksanakan program subsidi sekolah gratis berdasarkan Peraturan Bupati Gunung Mas No. 14 tahun 2009, (2) sumber utama pendanaan sekolah dari pemerintah, (3) dana BOS biasanya dikirim dalam bentuk pakaian siswa, (4) dana DAK diberikan dalam bentuk peralatan sekolah seperti alat-alat olah raga dan meubelair, dan (5) pembayaran honor guru GTT dilakukan oleh pemerintah daerah melalui Dinas Pendidikan sesuai UMR Provinsi Kalimantan Tengah.

\section{Komunikasi dalam Penyelenggaraan Program SD-SMP Satu Atap}

a) Komunikasi secara Intern pada SMP Satu Atap

Aspek komunikasi secara intern pada SMP Satu Atap terungkap dalam temuan penelitian lintas situs berikut ini: (1) komunikasi dilakukan setiap saat sesuai dengan keperluan dan berlasung secara formal maupun nonformal, (2) komunikasi secara nonformal dalam pergaulan sehari-hari dilakukan dengan bahasa daerah Dayak Ngaju, (3) kelancaran komunikasi secara lisan didukung oleh tempat atau ruangan yang jadi satu antara ruang kepala sekolah dengan guru-guru, (4) pesan disampaikan 
secara cermat dan disampaikan secara langsung tanpa menunda, (5) komunikasi sekolah dengan siswa berlangsung secara rutin di luar pembelajaran kelas, dilakukan setiap pagi hari di halaman sekolah untuk informasi atau pembinaan dan berdo'a bersama, dan (6) komunikasi dengan seluruh personal berjalan lancar dan akrab, serta berlangsung dengan penuh suasana kekeluargaan yang mencerminkan budaya rumah betang.

b) Komunikasi SMP Satu Atap dengan SD Penyangga

Aspek komunikasi SMP Satu Atap dengan SD penyangga terungkap dalam temuan penelitian lintas situs berikut: (1) pendataan siswa SD untuk alih jenjang SD ke SMP secara rutin setiap tahun, (2) alih jenjang dari SD ke SMP tidak dilakukan tes seleksi, (3) pada hari Jum'at sering didakan kegiatan bersama seperti olah raga, (4) melakukan upacara bendera bersama tiap hari Senin jika tidak hujan, dan (5) meskipun secara pengelolaan sekolah terpisah, tetapi nuansa "Satu Atap" masih sangat dirasakan dengan komunikasi yang lancar dan beberapa kegiatan dilakukan bersama SD penyangga sebagai wujud terhadap implementasi nilai-nilai budaya rumah betang.

c) Komunikasi SMP Satu Atap dengan UPTD/ Dinas Pendidikan Terkait Aspek komunikasi SMP Satu Atap dengan UPTD/ Dinas Pendidikan, terungkap dalam temuan penelitian lintas situs berikut: (1) komunikasi secara intensif dan proaktif oleh pihak sekolah, (2) komunikasi dalam bentuk usulan atau pelaporan secara rutin, urusan biaya rutin sekolah dan sebagainya, (3) secara struktural SMP Satu Atap langsung di bawah Dinas Pendidikan Pemerintah Kabupaten, dan (4) komunikasi dengan pihak UPTD Pendidikan di kecamatan hanya bersifat koordinatif.

d) Komunikasi SMP Satu Atap dengan Masyarakat Sekitar

Aspek komunikasi SMP Satu Atap dengan masyarakat sekitar terungkap dalam temuan penelitian lintas situs berikut: (1) terjadi komunikasi yang positif baik langsung maupun tidak langsung, (2) masyarakat menyambut baik keberadaan SMP Satu Atap, dan (3) komunikasi nonformal dilakukan dalam bentuk kegiatan kemasyarakatan dan keagamaan sebagai wujud implementasi nilai budaya rumah betang.

\section{Pembahasan}

\section{Struktur Birokrasi dalam Penyelenggaraan Program SD-SMP Satu Atap}

Pembahasan struktur birokrasi dalam penyelenggaraan program SMP Satu Atap tidak lepas dari pembahasan konsep birokrasi itu sendiri. Konsep birokrasi pertama kali dikenalkan oleh Weber (dalam Dwijowijoto, 2004: 63) yang mengemukakan bahwa, secara umum organisasi birokrasi memiliki karakter adanya struktur hirarkis yang baku, formal dan berjangka waktu panjang dengan prosedur-prosedur. Sedangkan Robbins (1998) mengemukakan, bahwa birokrasi dicirikan oleh tugas-tugas operasional secara rutin yang dicapai lewat spesialisasi dan aturan serta pengaturan secara formal. Kekuatan struktur birokrasi terletak dalam kemampuan menjalankan program secara efisien.

Berdasarkan penjelasan teoritis tentang birokrasi menurut beberapa ahli di atas, terkait dengan hasil penelitian menunjukkan bahwa dalam penyelenggaraan program SD-SMP Satu Atap di lokasi penelitian telah diaplikasikan teori struktur birokrasi yang disesuaikan dengan kondisi masingmasing sekolah. Di sisi lain, faktor kepemimpinan kepala sekolah dalam penyelenggaraan program sekolah juga menentukan, yaitu rata-rata menerapkan pendekatan situasional yang demokratis. Hasilnya terciptanya iklim sekolah yang kondusif dan terjadi efektifitas dan efisiensi sekolah yang didasari oleh nilai- 
nilai budaya, khususnya budaya rumah betang Kalimantan Tengah.

Berkaitan dengan uraian konsep birokrasi baik secara praktis maupun teoritis, maka dengan segala keterbatasan dimensi struktur birokrasi telah diselenggarakan dan berjalan secara efektif dan semaksimal mungkin yang dilakukan oleh kepala sekolah beserta semua guru dalam penyelenggaraan program SMP Satu Atap di daerah penelitian. Standar operasional kerja dilakukan secara cermat sesuai aturanaturan yang ditetapkan dalam petunjuk pelaksanaan. Koordinasi dengan semua komponen dilakukan secara aktif yang dilandasi oleh iklim kekeluargaan yang akrab. Efisiensi pemberdayaan sumber daya manusia dilakukan sesuai dengan kondisi sekolah yang serba terbatas untuk mencapai sekolah yang efektif (Bollen, 1997).

Berkaitan dengan pembahasan dimensi struktur birokrasi, hasil penelitian menunjukkan bahwa secara konseptual birokrasi telah diselenggarakan dengan cermat dan penuh kehati-hatian (pendekatan konsep). Sedangkan secara praktis dalam pelaksanaannya kepala sekolah rata-rata menggunakan pendekatan lapangan (field-approach) untuk mendukung penyelenggaraan program SMP Satu Atap yang ada di ketiga situs penelitian (SMPN Satu Atap 1 Mihing Raya, SMPN Satu Atap 2 Kurun, dan SMPN Satu Atap 3 Tewah). Jadi pendekatan lapangan yang dilakukan kepala sekolah, yaitu dengan pengorganisasian sekolah sesuai kondisi lingkungan sekolah yang ada (apa adanya), yang penting bagaimana sekolah bisa terselenggara dengan baik dan lancar. Sehingga dalam hal ini, salah satu budaya daerah yang berupa nilai-nilai budaya rumah betang yang meliputi nilai kebersamaan, kekeluargaan, dan loyalitas terhadap pimpinan dan sekolah akan memberikan andil yang besar dalam penyelenggaraan sekolah. Dengan demikian kearifan budaya lokal yang positif dapat dimanfaatkan dalam memperlancar dan menyelenggarakan program sekolah secara efektif, sehingga diperlukan kepemimpinan situasional yang kreatif dengan daya abstrak dan komitmen yang tinggi.

\section{Ketersediaan Sumber Daya pendidikan dalam Penyelenggaraan Program SD- SMP Satu Atap}

Ketersediaan sumber daya pendidikan merupakan dimensi yang tidak kalah pentingnya dalam mendukung keberhasilan penyelenggaraan program pendidikan. Walaupun program telah ditransmisikan secara akurat, jelas, dan konsisten, tetapi jika sumber daya tidak tersedia secara memadai untuk melaksanakan program, maka kemungkinan pelaksanaan program tidak akan efektif. Edward (1980) mengemukakan bahwa sumber daya merupakan faktor penting dalam mendukung keberhasilan penyelenggaraan program.

Dukungan sumber daya merupakan hal penting untuk menjaga kelangsungan organisasi (Castetter, 1996). Dukungan sumber daya dimaksud meliputi aspek sumber daya manusia, sumber daya fisik (prasarana dan sarana), dan sumber daya pendanaan atau pembiayaan. Hogwood dan Gunn (1984: 86) menyatakan bahwa, perpaduan sumber daya untuk mendukung penyelenggaraan program harus disediakan secara serentak. Perpaduan sumber daya dimaksud meliputi sumber daya manusia, sumber daya fisik (prasarana dan sarana), dan sumber daya pendanaan atau pembiayaan. Sehingga dalam penyelenggaraan program sekolah ketiga aspek dalam dimensi sumber daya harus dilakukan secara sinergi untuk mencapai tujuan sekolah yang efektif.

Berkaitan dengan pembahasan dimensi sumber daya baik secara praktis maupun teoritis, maka dengan segala keterbatasan keberadaan seluruh aspek sumber daya dapat mendukung 
penyelenggaraan program SMP Satu Atap yang ada di ketiga situs penelitian (SMPN Satu Atap 1 Mihing Raya, SMPN Satu Atap 2 Kurun, dan SMPN Satu Atap 3 Tewah). Hal tersebut tidak lepas dari nilainilai budaya lokal seperti budaya rumah betang sebagai latar dalam penyelenggaraan sekolah. Dengan nilai kebersamaan dan kekeluargaan, maka segala keterbatasan sumber daya dapat diatasi, misalnya penggunaan prasarana bersama antara SD dan SMP, hubungan yang harmonis antara sekolah dengan semua pihak. Dengan demikian keberadaan sumber daya tidak hanya menjadi tanggungjawab kepala sekolah saja, tetapi semua pihak.

\section{Komunikasi dalam Penyelenggaraan Program SD-SMP Satu Atap}

Pelaksanaan komunikasi secara empirik pada ketiga situs penelitian (SMPN Satu Atap 1 Mihing Raya, SMPN Satu Atap 2 Kurun, SMPN Satu Atap 3 Tewah) berlangsung efektif dan lancar. Hal ini tidak terlepas dari pengaruh kepemimpinan kepala sekolah dan implikasi iklim sekolah yang membawa nilai-nilai kebersamaan, kekeluargaan, loyalitas, dan keakraban yang terkandung dalam budaya rumah betang sebagai acuan norma sosial di masyarakat (Usop, 1994). Sehingga komunikasi mempunyai peranan yang penting dalam menunjang keberhasilan penyelenggaraan program sekolah.

Berdasarkan sejumlah penelitian empiris, dimensi komunikasi merupakan salah satu faktor yang menentukan pengembangan sekolah untuk menjadi sekolah yang efektif (Hopkins dan Lagerweij, 1996). Dalam melaksanakan tugas-tugas, banyak aturan yang harus dibuat. Komunikasi digunakan untuk menyebarkan informasi dan prosedurprosedur yang merupakan bagian dari budaya sekolah profesional secara bersama-sama dalam pertemuanpertemuan staf, sehingga tercipta hubungan-hubungan profesional yang baik antara personil sekolah.

Terkait dengan penyelenggaraan program sekolah, menurut Robbins (1998) dinyatakan bahwa komunikasi mempunyai empat fungsi utama dalam suatu lembaga atau organisasi, yaitu sebagai kendali (kontrol, pengawasan), motivasi, pengungkapan emosional, dan informasi. Dari keempat fungsi tersebut, dimensi komunikasi dalam penyelenggaraan program SD-SMP Satu Atap telah difungsikan terhadap sasaran secara baik dengan kondisi komunikatif positif. Sehingga meskipun dengan kondisi yang terbatas, penyelenggaraan program SD-SMP Satu Atap berjalan lancar tanpa ada hambatan yang berarti.

Koehler (1981) mengemukakan beberapa studi terakhir mengungkap komunikasi sebagai alat dalam manajemen. Dengan demikian komunikasi mempunyai pengaruh yang signifikan terhadap penyelenggaraan sekolah sebagai organisasi pendidikan untuk mencapai tujuan utama dalam pemerataan pencerdasan bangsa.

Pada pembahasan dimensi komunikasi, hasil penelitian menunjukkan bahwa komunikasi dengan berbagai komponen telah dilakukan secara lancar baik intern sekolah maupun ekstern sekolah (pihak lain di luar sekolah), baik secara formal maupun non formal. Menurut deskripsi beberapa ahli di atas, komunikasi merupakan faktor yang sangat penting untuk mendukung penyelenggaraan program SMP Satu Atap yang ada di ketiga situs penelitian (SMPN Satu Atap 1 Mihing Raya, SMPN Satu Atap 2 Kurun, dan SMPN Satu Atap 3 Tewah). Sehingga terselenggaranya program sekolah yang efektif juga didukung oleh kelancaran komunikasi antar berbagai pihak. Di sisi lain, budaya lokal seperti nilai-nilai budaya rumah betang juga memberikan "roh" dalam kelancaran komunikasi sekolah. 


\section{SIMPULAN}

Berdasarkan hasil penelitian dan pembahasan yang telah diuraikan sebelumnya, dapat dirumuskan kesimpulan sebagai berikut:

1. Acuan standar yang jelas dan koordinasi yang intensif, serta pemberdayaan sumber daya manusia yang tepat dengan pendekatan nilainilai budaya rumah betang seperti nilai kekeluargaan yang loyal dan akrab dalam struktur birokrasi dapat mencapai penyelenggaraan program SD-SMP Satu Atap secara efektif.

2. Sikap kreatif dan inovatif dalam pemberdayaan sumber daya pendidikan dengan nilai-nilai budaya rumah betang seperti nilai kebersamaan dan kekeluargaan yang akrab dapat mencapai penyelenggaraan program SD-SMP Satu Atap secara efektif.

3. Komunikasi secara intensif terhadap berbagai komponen dengan dasar nilainilai budaya rumah betang seperti kebersamaan, kekeluargaan, dan loyalitas yang akrab dapat mencapai terselenggaranya program SD-SMP Satu Atap secara efektif.

\section{UCAPAN TERIMA KASIH}

Ucapan terima kasih penulis sampaikan kepada para pihak Dinas Pendidikan Kabupaten Gunung Mas, Pihak SMPN Satu Atap 1 Mihing Raya, SMPN Satu Atap 2 Kurun, dan SMPN Satu Atap 3 Tewah, yang telah memberikan kemudahan akses serta dukungan moril selama penulis melaksanakan penelitian, serta Redaksi Equity in Education Journal (EEJ) yang telah memberikan kesempatan artikel saya dapat dimuat dalam jurnal ini.

\section{DAFTAR PUSTAKA}

Arikunto, S. (1998). Prosedur Penelitian: Suatu Pendekatan Praktek. Jakarta: Rineka Cipta.

Ary, D., Jacobs, L. C., \& Razavieh, A. (2002). Introduction to Research in Education. Sixth Ed. Belmont,
CA: Wadswort. Thomson Learning.

Bogdan, R. C., \& Biklen, S. K. (1998). Qualitative Research For Educatio: An Introduction to Theory and Methods. Third Ed. Boston : Allyn and Bacon.

Bollen, R. (1997). Making Good Schools: Linking School Effectiveness and School Improvement. London and New York: Routledge.

Brienkerhoof, D. W., \& Crosby, L. B. (2002). Managing Policy Reform: Concept and Tool for DecisionMakers in Developing and Transitionong Countries. United States of America: Kumarian Perss, Inc.

Castetter, W. B. 1(996). The Human Resources Function in Educational Administration (Sixth Edition). New Jersey: Prentice Hall, Inc.

Dunn, W. N. (1981). Public Policy Analysis: An Introduction. Englewood: Cliff, N.J. Prentice, Inc.

Dwijowijoto, R. N. (2004). Komunikasi Pemerintahan. Jakarta: Elek Media Komputindo Kelompok Gramedia.

Edward, G. (1980). Implementing Public Policy. Washington, DC. Congressional Quarterly, Inc.

Glickman, C. D., Gordon, S. P., \& RossGordon, J. M. (2009). The Basic to Supervision and Instructional Leadership. Secon Ed, Boston: Pearson.

Koehler. (1981). Organizational Communication, Behavioral Perspective. New York: Holt, Rinehart and Winston.

Kratzer. (1996). Marketing the Nation. New York: Free Press.

Kusni. J. J. (2006). Pergulatan Identitas Dayak Dan Indonesia: Belajar dari Tjilik Riwut Palangka Raya: Penerbit Galangpress. 
Equity in Education Journal (EEJ), Vol. 1, No. 1, Oktober 2019

Mantja, W. (2002). Manajemen Pendidikan dan Supervisi Pengajaran (Kumpulan Karya Tulis Terpublikasi). Malang: Wineka Media.

Mantja, W. (2008). Ethnography, Desain Penelitian Manajemen Pendidikan. Malang: Elang Mas.

Nasution, S. (1998). Metode Penelitian Naturalistik Kualitatif Bandung: Transito.

Peraturan Pemerintah RI Nomor 47 Tahun 2008. Wajib Belajar. Bandung: Penerbit Citra Umbara.

Robbins, S., P. (1998). Organizational Behavior. New Jersey: Englewood Cliffs.

Sonhadji. K. H. A. (1996). Teknik Pengumpulam Data dan Analisis Data dalam Penelitian Kualitatif dalam Arifin. Penelitian Kualitatif. Malang: Kalimasahda Press.

Sugiyono. (2006). Metode Penelitian Administrasi. Bandung: Alfabeta.

Undang-Undang Dasar Republik Indonesia Tahun 1945. Bandung: Penerbit Citra Umbara.

Undang-Undang Republik Indonesia Nomor 20 Tahun 2003 tentang Sistem Pendidikan Nasional. 2006. Bandung: Pcnerbit Citra Umbara.

Usop, K. M. A. (1994). Pakat Dayak: Sejarah Integrasi dan Jati Diri Masyarakat Dayak dan Daerah Kalimantan Tengah. Palangka Raya: Yayasan Dikbud Batang Garing.

Winarno, B. (2002). Kebijakan Publik: Teori dan Proses. Yogyakarta: Media Pressindo. 